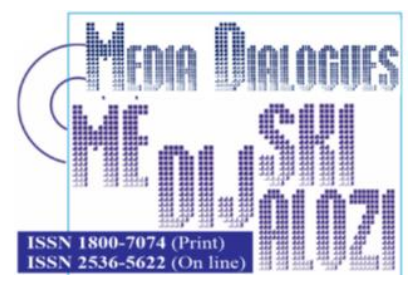

Jovovic, R., Jovovic, N. (2013), ,Journalism in New Economy: Profesional Identity and Idependency", Media Dialogues / Medijski dijalozi, Vol. 14, No. 2, pp. 51-58.

\title{
Journalism in New Economy: Profesional Identity and Idependency
}

\author{
Professor RADISLAV JOVOVIC, \\ Mediterranean University, Faculty of Business Studies, \\ Podgorica, Montenegro \\ PhD Student NEBOJSA JOVOVIC, \\ Mediterranean University, Faculty of Business Studies, \\ Podgorica, Montenegro
}

\begin{tabular}{|c|c|}
\hline $\begin{array}{l}A R T I C L E \\
I N F O\end{array}$ & $\begin{array}{c}\text { Received: November 08, } 2019 \text { / Revised from: December 08, } 2019 \\
\text { Accepted: January 15, } 2020 / \text { Available online: October 15, } 2020\end{array}$ \\
\hline $\mathrm{DOI}$ & doi.org/10.14254/1800-7074/13-4/5 \\
\hline
\end{tabular}

\begin{abstract}
Society today is awash in junk information that offten is contaminating not only responsible journalism but also the very ability of democracies to make sound decisions in their own best interests. Science is of necessity caught up in this world in which fantasy now fetches a market premium over fact. Major scientific questions and issues are being fought out and decided on emotional rather than factual grounds. Of equal concern is the rise of pseudo-science on TV, with themes of science
\end{abstract}


fiction, "strange but true" or "alternative" remedies. These further confuse an already baffled public, which is having trouble telling the difference between science fact and fiction because of the indiscriminate way in which the media presents them. A society unable to discriminate between real and imaginary threats has poor prospects for long-term survival. It is time to again make a clear separation between reporting and entertainment - before our society pays a high price for living in the New, Information Age.

KEYWORDS: Identity of journalist, objectivity, neutrality, technological development, communications, changes

\section{INTRODUCTION}

Journalists are professionals and should act accordingly. The common norms of journalism vary between countries, but the existence of an ideological base is a general phenomenon - it is the professional identity that makes the journalist. What today influence the professional indtity? The answer in not easy. We regard this identity as a composition of various journalistic ideals, such as objectivity, neutrality, and scrutiny. But these ideals changes over time. Our intention is not to identify the direction of this change but to analyse journalism transition, in view of its scrutinizing function in society. The increasingly consumerist society and tougher competition in media markets has accentuated the difficulties in achieving these high ideals (objectivity, neutral- ity, and scrutiny), but has at the same time opened up new needs for audience contact and feedback. Extend, and dynamics fo modern changes have affected the nature of work of journalsit. Pace, extent and dynamics of modern changes, that have brought globalization and information society, are more revolutionary than ever.

Generally, dynamic of change and technological change are especially dominant feature of today. It was followed by the creation of a superactive development strategies and appropriate activities for their realization. They are based on the idea of progress as a permanent process of development of knowledge and science, followed by the formation of new social structures and organizations. Innovative organization is based on continuous learning, ie. specialization of existing and new knowledge, which are a function of the application and/or the creation of new technologies. With-out innovation, changes have cosmetic character and they are short term. Constant innovation, evolutionary and revolutionary, is necessary for the development. The pace of change is increasing exponentially.

Technological renovation is indinspensable in every industry and/or organization that strives for success, survival and sustainable development. Therefore, the choice of modern business is very simple: „To be quick or quickly forgot-ten!” 
Technological progress is supported by constant expansion of capital, its investment into profitable business and awakened competition. That is how new developments and technological progress is stimulated, as a result of knowledge. It has virtually limitless potential to create and improve everything that exists. Technological innovations affect the significant improvement of company performance, creation of competitive advantages and competencies. New technologies create new opportunities, remove barriers to international trade and investment, increase transparency and diversification opportunities, intra-corporate exchange and virtualization.

Innovations in information technology, computer networks, telecommunications and transportation systems have contributed to connecting the market at all distances and areas.. The leaders are the global „boom” of information, communication, and transport monitoring. Technological superiority is usually accompanied by modern organizational skills, marketing and managerial know-how and expansion of the service sector. As a result of the technological revolution, the share of services in creating GDP is increased. The best example is the U.S. with 73\% in 1990 (Statistical Abstract of the Unitetd States, 1995, p. 452).

\section{IMACT OF TECHOLOGY CHANGES ON MEDIA}

The democratic role of journalism may indeed differ depending on the democratic model prevailing: participatory, liberal or oriented towards competition. We think that models of new economy are based on oppenes, colaboration, transparency, and knowledge. In that sence, new media has sometimes been depicted as the death of traditional news media, as practically anyone with a computer can now go online and publish. Mobile phones and digital cameras have also had great influence on the formation and speed of news: a journalist may no longer be first on spot at news events since any citizen can now pick up a camera and deliver the first shot. Moreover, it is equally easy to set up a news portal, collect available news sources and thus create a non-journalist selection of news. The blogosphere and its implications for democracy, politics and identity-creation have therefore been widely discussed. Overall, new in- struments of communication have opened up publishing opportunities to virtually every citizen. The deliberative effects of digital media can indeed be questioned, but it has indubitably changed influences on media consumer patterns and media production.

With massive changes in the media environment and its technologies, interrogating the nature of news journalism is one of the most urgent tasks we face in defining the public interest today. The implications are serious, not just for the future of the news, but also for the practice of democracy. The essential notion is that journalism traditionally has been very effective at shining a spotlight on the problems and developments of the day. But, traditional journalism, for a variety of reasons, has often failed to place those stories in enough contexts to understanding them fully. 
One of the most significant reasons has been technological. Moreover, the traditional, analog media have been largely one-way in their information flow, from the journalist to the public. This passive audience model has limited the involvement or engagement of the public in journalism and public affairs.

Without a doubt, this new technology will change journalism. It is up to society to make sure that this change is for the better. If the free press and journalistic ethics are to survive the treacherous journey into cyberspace, society needs to answer the tough questions that new technology will raise about the role of journalism in a free society, remembering that technology, no matter how powerful, can only be as useful and worthwhile as human beings decide to make it. As E.R. Murrow warned many years ago, technology without thoughtful human involvement is merely "lights and wires in a box".

\section{IMPACT OF "NEW" MARKET LOGIC ON JOURNALISM}

In practice, IT, telecommunications, innovation, organization, globalization and other developments and events undoubtedly make the economy „new”. The latest technological revolution (especially in the field of communications and transport, which use micro-processors, fiber optics, databases, computers, digital networks, lasers, etc.) has great economic implications. The most important is creating the basic infrastructural requirements for the socalled post-industrial (post-Fordist) era, that relativizes the number of differences (spatial, temporal, cultural, ethical, political, ideological and others) and verifies the theory of convergence, but not the economic convergence. All these changes have contributed to the market transparency, reducing the information searching costs, deregulating and dominating the customers market.

The market discourse conveys a turbulent environment, blurring the boundaries between professions since multiple work tasks now have to be done by the same person. It is said to force commercial thinking upon professionals, and erode the mysterious exclusivity of professional knowledge as it becomes available to the public (Fournier, 2000). Fournier effectively reveals the origin of this discourse in essentialist assumptions of the market nature as well as of professional knowledge. Instead, she argues the imagination of professional fields as independent, autonomous and self- contained entities to actually be achievements of the professional project. The field of professional knowledge is thus always in motion and expanding: ,the object that it claims to know about is not independent of the professional gaze, but is constituted by professional practice" (Ibid., 72).

This market transparency is important chelenges for journalists. We would say it is alarming threat to journalistic freedom is, according to media critical debate, the ubiquitous influence of the market - referred to under the names of commercialization, commoditization or tabloidization etc (e.g. Picard, 2004, McManus, 1994, Kea- 
ne, 1991). Some authors (Reinardy) even talks of a crisis in professional journalism since ,plummeting circulation, declining revenues, new technology, conglomerate ownership, and layoffs s" mainly in the newspaper industry have contributed to an increasingly tough working environment for journalists. Repeated editorial budget cuts, low salaries and job insecurity are causing a decline in professional commitment and efficacy; trends eventually leading to cynicism, burnout and detachment from professional aims. American editors and journalists who, in a Pew Research Centre Survey from 1999, stated that growing business and financial pressures were harming quality of coverage (Pew, 1999).

The influence of market logic on a professional field can work in three main ways: Firstly, by challenging the boundaries between practitioners and laymen (i.e. journalists and audience), as the passivity of the 'laymen' can no longer be taken for granted. Secondly, the line between publicity ideals and market ideals gets blurred as the public transforms into customers whose taste and demands become imperative. And thirdly, deregulation and broken monopolies as well as technological change require professionals to prime multi-functionality instead of speciality (Fournier, 2000). Translating this influence into a journalistic context means, for instance, that the audience is decreasingly dependent on journalism as the only arena for information and debate. Furthermore it places the role of journalism in a changing position; while the field always mirrored the dominating class, and its inherent tension between an intellectual pole and an economic pole, it is now increasingly moving towards the economic side.

This shifting between poles has its own logic because the dominant class has an interest in confusing them. Embodied in the hybrid figure of the „media intellectu$a l$ " is namely the economically successful journalistic enterprise where the original tension has been washed off. Such an image implies synonymity between proper and profitable journalism; in the end, large circulation numbers may not be proof of a top quality news paper, but poor circulation is always perceived as failure. Even so, the absence of money talk has been one of the most remarkable features of journalistic culture. Journalists seem extremely unwilling to explore that side of reality, since it would ruin the hegemonic lore of the profession, and as a consequence threaten the alleged field autonomy (Altschull, 1997).

\section{IMPACT OF GLOBALIZATION ON JOURNALISM}

The bond between journalism and politics is very complex, and it is case in new economy. Political influence in the field of journalism can work in different ways, and relations diverge in various national contexts. Also, globalization has genereted all the maior changes whic have hudge effect on politic. People are getting closer in space and time, but they are estranged due to the growing economic and social inequalities. The rise of the information economy is marked by the development of a new organizational logic, associated with a current process of technological change. 
Inter- action between the new technological paradigms and new organizational logic is not a historic backbone of new economy.

As globalization creates massive transboundary flows that transcend the boundaries of geographically defined nation- states, it tightly binds together the for- tunes and relations of people and institutions around the world. In fact, Anthony Giddens, from the London School of Economics (LSE), defines globalization as "the intensification of worldwide social relations which link distant localities in such a way that local happenings are shaped by events occurring many miles away and vice ver$s a . "$ In a tightly integrated economy, a financial meltdown in one region can immediately impact the economies on the other side of the world, while investment decisions made on Wall Street, can rapidly shift money, jobs and production from one community to another.

The nuclear meltdown in Chernobyl shows that environmental disasters know no national boundaries, just as the flow of drugs, diseases and weapons moves readily from continent to continent. As the world shrinks, we become ever more aware of the multi-leveled ways our fortunes are overlapping. This phenomenon, often referred to as time-space compression, is intensified as the Internet and a global media system not only render the distant more proximate, but also reinforce our consciousness of this interconnectedness.

Regarding influence on the identity of journalists, the challenges of new political arena are yet not illuminated. The new arena requires the corresponding traits. Deuze (2005) found some main ideal-typical traits (i.e. ideals) in an overview of literature describing: public service, journalists provide a public service; objectivity, journalists should be impartial, fair and credible; autonomy; journalists should be free and independent in their work; immediacy, journalists should have a sense of actuality and speed; and finally ethics, journalists should have a sense of ethics and legitimacy. Deuze does not consider these values as static or definite in any sense, but notices that, in various combinations, they represent what western journalism researchers tend to think of as 'real' journalism. We would point that in spite of different working conditions, there were indeed some shared conceptions of news - in other words, a trans-national journalistic culture.

Even in more transparent world, the political field can describe a wide field of power, but also refer specifically to state agencies and elected bodies (Benson, 2005). The obvious link between journalism and politics is through ownership, media content and the journalist-source relation. Wielding symbolic power is not specific to the political field, but asserting power through laws and regulations is. Media policy is therefore an important classification factor when trying to put a journalistic field into an international context.

Another direct exercise of political power over media is through ownership. The media are in some countries owned by the state, which extensively limits the autonomy of the journalistic field. A more common order of the Western sphere is that 
political parties stand as owners of media companies or that media owners explicitly sympathize with political agendas. That way, political influence is separated from state power. On the other hand, state controlled public service media is generally con- sidered as a means to strengthen journalistic autonomy and pluralism. Through a legally established system and financed by some sort of public funding, public service media are allowed a large degree of editorial and operating independence. The goal is to offer varied, qualitative and impartial coverage that concerns the population as a whole, including different minorities (McQuail, 2005).

The interplay between politicians and media representatives also extends to the practical coverage of politics. Bourdieu concluded the journalistic field to be subordi-nate to the political, since it is so largely confused by hierarchies of the political system (Bourdieu, 1998). This sub-ordination is made possible as journalists absorb the relative importance of political institutions. The news value of political themes and figures are decided from the institutionalized authority as constituted in journalists' minds. Therefore the most successful journalists are those who best assimilate the dogmas supporting the government and social order as a whole (Darras, 2005).

\section{CONCLUSION}

Opposing the transforming (and sometimes destructive) forces of market liberalism and bureaucratization, traditional journalistic ideals have attained extensive support over time, and the efforts to fix professional boundaries are strong. The struggle serves to defend traditional values and all the consequences for journalism at different levels are yet not illuminated. We would like to call attention to further areas that still need to be researched: in order to capture „new” ideals of commercial character. We believe, for instance, increasing audience orientation and incorporation of market values into the professional identity to be possible elements of the ongoing adaption process. Standard professional criteria framing most surveys are not at all irrelevant - especially not in comparative studies, but in a time sequence like mine the difficulty of measuring change in terms of new values becomes a problem.

There is, of course, also the matter of linking ideals and practice: Professionalism controls practice and when practice places new demands on journalists, this will in turn affect their professionalism. This does not automatically mean, however, that it will dissolve the collective, or even lower the total degree of professionalism. Further investigation into the nature and mechanisms of professional identities will allow us to carry on a nuanced discussion of the future role of journalism - whatever we wish this to be. 


\section{REFERNCES}

Altschull, H. J. (1997), „Boundaries of Journalistic Autonomy“ in Berkowitz, D., Ed., Social meaning of news, Sage, Thousand oaks.

Benson, R. (2005), „Mapping field variation: Journalism in France and the United States“ in Benson, R. \& Neveu, E. (Eds.), Bourdieu and the Journalistic Field. Cambridge, Polity Press.

Bourdieu, P. (1998), On television, New York, New Press. Darras, E. (2005), „Media Consecration of the Political Order" in Benson, R. \& Neveu, E., Eds. Bourdieu and the Journalistic Field, Polity Press, Cambridge.

Deuze, M. (2008), „The Professional Identity of Journalists in the Context of Convergence Culture. Observatorio“, Journal, Vol. 7, pp. 103-117.

Draskovic, V., Jovovic, R., Lakic, S., Rutovic, Z., Draskovic, M. (2010), Globalization in the Mirror of Development, Crisis and Media, Elit, Podgorica (in Serbian).

Draskovic, V., Jovovic, R., Draskovic, M., Jereb, B. (2013), Knowledge - Keastone of The Modern Economy, SPH, Celje-Osijek-Czestochowa-Kotor.

Fournier, V. (2000), „Boundary work and the (un)making of the professions“ in Malin, N. (Ed.), Professionalism, Boundaries and Workplace, pp. 67-87, Routledge, London.

Florence, KY, Routledge. Hadenius, S., Weibull, L. Wadbring, I. (2008), Massmedier: press, radio och TV i den digitala tidsåldern, Ekerlid, Stockholm.

Keane, J. (1991), The media and democracy, Cambridge, Polity Press, Thousand oaks, Calif., Sage.

Mcmanus, J. H. (1994), Market-driven journalism: let the citizen beware?, Thousand oaks, [Calif.], Sage.

PEW (1999), Striking the Balance, Audience Interests, Business Presures and Journalists' Values, Pew Research Centre for the People and the Press.

Picard, R. G. (2004), „Commercialism and Newspaper Quality“, Newspaper Research Journal, vol. 25, pp. 54-65.

Picard, R. G. (2009), Why Journalists Deserve Low Pay, The Christian Science Monitor.

Reinardy, S. (2007), Newspaper journalism in crisis: burnout on the rise, eroding young journalists' career commitment, Washington D.C., Association for Education and Mass Commu- nication convention, Newspaper Division.

Wiik, J. (2010), Journalism in Transition, Litorapid Media AB, Göteborg. 